Revised pre-print of

Damien Barbaras, Marcel Kaiser, Reto Brun, Karl Gademann

Bioorg. Med. Chem. Lett. 2008, 18, 4413-4415.

DOI: http://dx.doi.org/10.1016/j.bmcl.2008.06.049

\title{
Potent and Selective Antiplasmodial Activity of the Cyanobacterial Alkaloid Nostocarboline and its Dimers
}

\author{
Damien Barbaras, ${ }^{\mathrm{a}}$ Marcel Kaiser, ${ }^{\mathrm{b}}$ Reto Brun $^{\mathrm{b}}$ and Karl Gademann ${ }^{\mathrm{c}, *}$ \\ ${ }^{a}$ Laboratorium für Organische Chemie, Swiss Federal Institute of Technology (ETH), 8093 Zürich, Switzerland \\ ${ }^{b}$ Parasite Chemotherapy, Swiss Tropical Institute (STI), 4002 Basel, Switzerland \\ ${ }^{c}$ Chemical Synthesis Laboratory, Swiss Federal Institute of Technology (EPFL), 1015 Lausanne, Switzerland
}

This is where the receipt/accepted dates will go; Received Month XX, 2000; Accepted Month XX, 2000 [BMCL RECEIPT]

\begin{abstract}
The quaternary $\beta$-carbolinium alkaloid nostocarboline from the cyanobacterium Nostoc 78-12A and ten bis-cationic dimeric derivatives were evaluated against four protozoan parasites and low micromolar values against Trypanosoma brucei, submicromolar values against Leishmania donovani and low nanomolar values against Plasmodium falciparum K1 were determined. Selectivity against rat myoblasts (L6 cells) was found to be up to > 2500 fold. (C2008 Elsevier Science Ltd. All rights reserved.
\end{abstract}

Malaria remains a public health problem in large areas of the developing world, with $40 \%$ of the earth's population living in malaria-endangered areas. ${ }^{1}$ As a direct consequence, over 1 million humans die annually of this disease, with the number of clinical cases estimated to be a hundred times higher. ${ }^{2}$ These public health problems are accentuated by the rise of malaria cases in yet non-endemic areas, and increasing resistance of Plasmodium to current lines of therapy. These facts combined with the absence of a vaccine and the lack of systematic vector control strategies provides the rationale for the development of novel drugs against this disease. $^{4}$

Natural products are extremely successful in providing mankind with substances to combat diseases, and today, roughly $50 \%$ of all small molecule drugs on the market addressing infectious diseases are natural products or derivatives thereof. ${ }^{5}$ With respect to malaria, quinine and its derivatives are still in use today, and new therapies based on artemisinin were recently introduced in the clinic. ${ }^{4}$ Cyanobacteria have been shown to be an important source for novel bioactive natural products, as these organisms face large pressure from grazers or competing organisms requiring them to develop chemical defense strategies. ${ }^{6}$ Several cyanobacterial metabolites have been shown to possess antiplasmodial activity: Calothrixins A and B inhibited the FAF6 strain of Plasmodium falciparum with $\mathrm{IC}_{50}$ values of roughly 60 and $180 \mathrm{nM}$, albeit with no or very little selectivity against HeLa human tumor cell lines. ${ }^{7 a}$ Venturamide B displayed a low micromolar value against Plasmodium falciparum W2 with a selectivity $>10$ against green monkey Vero kidney cells reported. ${ }^{7 \mathrm{~b}}$ Symplocamide A displayed an $\mathrm{IC}_{50}$ value of $0.95 \mu \mathrm{M}$ against the same strain, but rather strong cytotoxicity. ${ }^{7 \mathrm{c}} \mathrm{We}$ have recently isolated nostocarboline (1), an acetyl- and butyrylcholinesterase, and trypsin inhibitor from Nostoc 78$12 \mathrm{~A} .{ }^{8}$ Moreover, this compound class has been shown to possess strong algicidal activity against both eukaryotic and prokaryotic phototrophs. ${ }^{9}$ The chemical ecology rationale for evaluating nostocarboline against Plasmodium was based on a large body of research demonstrating that Plasmodium contains a plastid-like organelle, which was suggested to be a relic of a photoautotrophic (cyanobacterial) endosymbiont. ${ }^{10}$ Targeting this apicoplast with algicidal compounds has been suggested as a strategy for effective antiplasmodial

Keywords: Antiprotozoal, Malaria, Natural Products, Synthesis, Pentamidine

* Corresponding author. Tel.: + 412169393 15; Fax: + 412169397 00;

e-mail: karl.gademann@epfl.ch 
agents. ${ }^{11}$ In this communication, we demonstrate that nostocarboline (1) inhibits Plasmodium with high selectivity in nanomolar concentrations. In addition, we demonstrate that dimerization of nostocarboline leads to very potent and selective antiplasmodial agents. This latter route presents a strategic option for the chemical diversification of natural products ${ }^{12}$ and provides an entry into bis-cationic compounds, a class of compounds known for strong antiplasmodial activity. ${ }^{13}$

Nostocarboline (1) was synthesized according to published procedures starting from norharmane via chlorination at C-6 and methylation (Scheme 1). ${ }^{8 \mathrm{a}} 6-\mathrm{Cl}-$ norharmane was also the starting material for the synthesis of nostocarboline homo-dimers, which were prepared using symmetrical dihalogeno-linkers to afford the desired bis- $\beta$-carbolinium homo-dimers 2-11 (Table 1). We were able to employ alkenyl, alkynyl, aryl and biaryl, as well as alkyl linkers of various lengths for the corresponding dimers, which were obtained in a twostep process and isolated in good to excellent yields. It should be pointed out that cheap, short and highyielding syntheses should be regarded as a requirement for successful antimalarial agents, given the prevalence of this disease in developing countries.

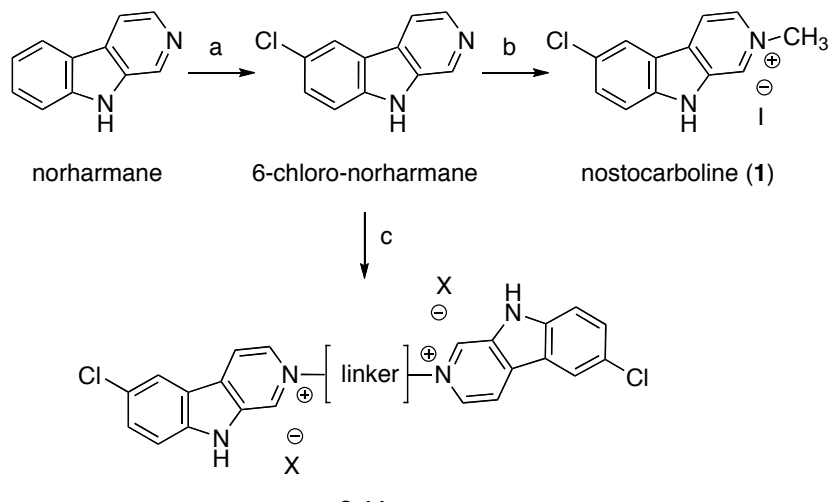

2-11

Scheme 1. Reagents and conditions: (a) $\mathrm{NaOCl}, \mathrm{EtOH}, 0{ }^{\circ} \mathrm{C}, 30 \mathrm{~min}$, then r.t., $5 \mathrm{~h}, 75 \%$; b) $\mathrm{CH}_{3} \mathrm{I}, i$-PrOH, reflux, $4 \mathrm{~h}, 94 \%$; c) dihalogeno-linkers, $i$ $\mathrm{PrOH}$, reflux, $12-48 \mathrm{~h}, 60-95 \%$.

Nostocarboline (1) as well as its dimers 2-11 were evaluated against four parasites, Trypanosoma brucei rhodesiense STIB 900, Trypanosoma cruzi Tulahuen C2C4, Leishmania donovani MHOM-ET-67/L82 axenic amastigotes, and Plasmodium falciparum $\mathrm{K} 1$ and the corresponding $\mathrm{IC}_{50}$ values are given in Table 2 . Nostocarboline (1) showed a pronounced activity against Plasmodium $\left(\mathrm{IC}_{50}=194 \mathrm{nM}\right)$, while being inactive against the other parasites tested. In addition, nostocarboline (1) showed very weak cytotoxicity (> $0.1 \mathrm{mM}$ ), giving rise to a 600 fold selectivity of Plasmodium over L6 cells. The results for the dimers 2$\mathbf{1 1}$ display a consistent pattern of activity: While against T. brucei $\mathrm{IC}_{50}$ values around $1 \mu \mathrm{M}$ were determined, the dimers 2-11 were roughly by a factor of 5 to 50 less active against $T$. cruzi. Interesting submicromolar activity against $L$. donovani could be determined for some dimers, in particular those incorporating a long, flexible linker such as 7-11. In this series, higher activity nicely correlates with longer linkers. Interestingly, the most active compound was the dimer 5 with the meta substituted aryl linker $(0.2 \mu \mathrm{M})$, which was roughly 100 fold more active than dimer 4 with the corresponding para substituted linker. This suggests that relative orientation of the two nostocarboline units has an impact on activity against $L$. donovani.

Table 1. Structure of bis- $\beta$-carbolinium homodimers 2-11.

\begin{tabular}{|c|c|c|c|}
\hline Compound $^{\mathrm{a}}$ & Linker & Time (h) & Yield (\%) \\
\hline 2 & & 12 & 72 \\
\hline 3 & & 12 & 65 \\
\hline 4 & & 12 & 95 \\
\hline 5 & & 12 & 89 \\
\hline 6 & & 12 & 86 \\
\hline 7 & & 24 & 60 \\
\hline 8 & & 48 & 93 \\
\hline 9 & & 48 & 87 \\
\hline 10 & & 48 & 78 \\
\hline 11 & & 48 & 71 \\
\hline
\end{tabular}

The best results were obtained against Plasmodium falciparum, where submicromolar $\mathrm{IC}_{50}$ values were determined for all dimers 2-11. In this series and against this parasite, long and flexible linkers are preferred, with the corresponding compounds 6-11 all displaying $\mathrm{IC}_{50}$ values below $100 \mathrm{nM}$. The most active compound 10 containing a $\left(\mathrm{CH}_{2}\right)_{10}$ linker displayed an $\mathrm{IC}_{50}$ value of 14 nM against $P$. falciparum K1.

We also determined cytotoxicity against the L6 rat myoblast cell line, and the values were generally dispersed in the 5-60 $\mu \mathrm{M}$ range. While the effect of linker length on antiplasmodial activity residues for 711 was very small, its effect on cytotoxicity was more pronounced. Clearly, cytotoxicity increased with linker length, thus leading to decreased selectivity for longer linkers. Compounds $\mathbf{7}$ and $\mathbf{8}$ with 5 and 6 atom linkers can thus be considered optimal in this series, as e.g. 7 displayed high potency (18 $\mathrm{nM})$ and an excellent selectivity of $>2500$ fold against the L6 cell line.

These results complement the interesting biological profile of nostocarboline: While this compound strongly 
inhibits the growth of cyanobacteria and eukaryotic chlorophytes, it is inactive against bacterial pathogens and fungi, ${ }^{9}$ and very weakly toxic against mammalian eukaryotic cells (Table 2) and crustaceans. ${ }^{8 \mathrm{~b}}$ At the same time, activity against Plasmodium was observed. It is tempting to speculate that this activity might be correlated with the presence of plastids of cyanobacterial origin in Plasmodium, where the actual targets of nostocarboline might be present. Whether these targets are related to the known inhibitory action of nostocarboline on hydrolytic enzymes such as esterases and proteases must be validated. It is also unclear at present, whether nostocarboline and its dimers 2-11 act via the same mode of action on Plasmodium: The increased cytotoxicity (and decreased selectivity) of some of the dimers suggests a competing non-selective pathway for some dimers (e.g. 4 and 5).

Table 2. Antiparasitic in vitro activities of 1-12 (values in $\mu \mathrm{M}$ ).

\begin{tabular}{|c|c|c|c|c|c|c|}
\hline & $\begin{array}{l}T . b .^{\mathrm{a}} \\
\mathrm{IC}_{50}\end{array}$ & $\begin{array}{l}\text { T. } c .^{\mathrm{b}} \\
\mathrm{IC}_{50}\end{array}$ & $\begin{array}{l}L . d^{\mathrm{c}} \\
\mathrm{IC}_{50}\end{array}$ & $\begin{array}{l}P . f^{\mathrm{d}} \\
\mathrm{IC}_{50}\end{array}$ & $\begin{array}{c}\text { Cytotoxicity }^{\mathrm{e}} \\
\mathrm{IC}_{50}\end{array}$ & $\begin{array}{c}\text { Selectivity } \\
\text { P. } f .\end{array}$ \\
\hline 1 & 70.5 & $>87.1$ & 34.3 & 0.194 & 120.9 & 622 \\
\hline 2 & 1.1 & $>56.6$ & 9.6 & 0.113 & 61.1 & 540 \\
\hline 3 & 6.4 & 10.6 & 34.7 & 0.738 & 28.5 & 39 \\
\hline 4 & 1 & $>51.7$ & 19.9 & 0.223 & 17.4 & 78 \\
\hline 5 & 1.2 & 5.9 & 0.2 & 0.121 & 3.8 & 32 \\
\hline 6 & 2.5 & $>45.7$ & 68.4 & 0.056 & 23 & 408 \\
\hline 7 & 1.2 & 51.1 & 8.6 & 0.018 & 47.9 & 2625 \\
\hline 8 & 1.2 & 36.2 & 6.6 & 0.020 & 36.2 & 1810 \\
\hline 9 & 0.9 & 31.4 & 2.3 & 0.018 & 7.5 & 423 \\
\hline 10 & 1.1 & 36.6 & 0.9 & 0.014 & 8.2 & 575 \\
\hline 11 & 1.2 & 10 & 0.6 & 0.023 & 4.3 & 186 \\
\hline 12 & 92.5 & $>44.6$ & 61.6 & $>7.4$ & 121.3 & n.d. ${ }^{g}$ \\
\hline
\end{tabular}

${ }^{\text {a }}$ Trypanosoma brucei rhodesiense STIB 900

${ }^{\mathrm{b}}$ Trypanosoma cruzi Tulahuen $\mathrm{C} 2 \mathrm{C} 4$

${ }^{\mathrm{c}}$ Leishmania donovani MHOM-ET-67/L82

${ }^{\mathrm{d}}$ Plasmodium falciparum K1

${ }^{\mathrm{e}}$ Rat myoblast L6 cells

${ }^{\mathrm{f}}$ The selectivity index is calculated by $\mathrm{IC}_{50}(\mathrm{~L} 6) / \mathrm{IC}_{50}(P . f$.

${ }^{g}$ n.d.: not determined

An interesting compound to evaluate the mode of action, as well as potential resistance mechanisms, is the hybrid 12 of nostocarboline and ciprofloxacin (Figure 1). ${ }^{9}$ Such dual mode of action hybrids combine the distinct bioactivity of two different fragments leading to synergistic mode of action. ${ }^{14}$ We have shown that $\mathbf{1 2}$ retains the activity of nostocarboline, with increased properties against some bacteria. ${ }^{9}$ Interestingly, against the parasites evaluated, compound $\mathbf{1 2}$ was found to be inactive (Table 2).

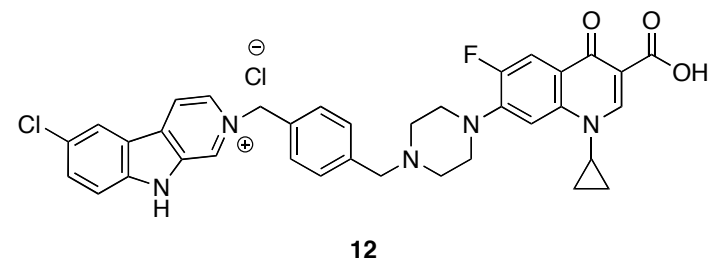

Figure 1. Structure of the quinolone $\beta$-carbolinium hybrid 12.

The results obtained in this study also favorably compare to other carbolinium natural products with antiplasmodial activity, such as e.g. normelinonine $\mathrm{F}^{15 \mathrm{a}}$ fascaplysin, ${ }^{15 \mathrm{~b}}$ and cryptolepine ${ }^{15 \mathrm{a}, 15 \mathrm{c}}$. While the activities of these natural products against Plasmodium falciparum are comparable, higher selectivity was observed for nostocarboline (1). The tetra- and pentacyclic framework of cryptolepine and fascaplysine appear to increase DNA intercalation properties resulting in increased unspecific cell toxicity ${ }^{15}$. In addition, while natural dimeric cryptolepine alkaloids were inactive against Plasmodium, ${ }^{15 c}$ synthetic nostocarboline dimers such as $\mathbf{7}$ resulted in significantly higher activity.

In conclusion we have shown that nostocarboline (1) and its symetrical homodimers 2-11 are potent and selective inhibitors of Plasmodium falciparum and display also interesting activity against Leishmania donovani. The compound with the best profile was dimer 7, with an $\mathrm{IC}_{50}$ against Plasmodium falciparum of $18 \mathrm{nM}$ and a $>2500$ fold selectivity against L6 cells. The benefits of the presented compounds thus include (1) ease of synthesis in two steps from norharmane; (2) potent activity down to $14 \mathrm{nM}$ against Plasmodium falciparum and (3) weak cytotoxicity resulting in selectivities of up to $>2500$ fold. The elucidation of the mode of action as well as evaluation in animal models is now being carried out in our laboratories.

\section{Acknowledgments}

K. G. is a European Young Investigator (EURYI). Financial support from ETH Zürich (TH Gesuch 13/04$3, \mathrm{PhD}$ fellowship to D.B.) is gratefully acknowledged.

\section{References and notes}

1. (a) Blond, P. B. World Health Organ. 2001, 27; (b) Baird, J. K. N. Engl. J. Med. 2005, 352, 1565; (c) Daily, J. P. J. Clin. Pharmacol. 2006, 46, 1487.

2. (a) Breman, J. G. Am. J. Trop. Med. Hyg. 2001, 64, 1; (b) Sachs, J.; Malaney, P. Nature 2002, 415, 680; (c) Snow, R. W.; Guerra, C. A.; Noor, A. M.; Myint, H. Y.; Hay, S. I. Nature 2005, 434, 214.

3. (a) Ridley, R. G. Nature 2002, 415, 680; (b) Sidhu, A. B.; Fidock, D. A. Science 2002, 298, 210; (c) Hyde, J. E. Trends Parasitol. 2005, 21, 494; (d) Reed, Z. H.; Friede, M.; Kieny, M. P. Curr. Mol. Med. 2006, 6, 231; (e) Lanzer, M.; Rohrbach, P. Curr. Science 2007, 92,1561 . 
4. Reviews on chemotherapeutics against malaria, see: (a) Wiesner, J.; Ortmann, R.; Jomaa, H.; Schlitzer, M. Angew. Chem. Int. Ed. 2003, 42, 5274; (b) Schlitzer, M. ChemMedChem 2007, 2, 944.

5. Newman, D. J.; Cragg, G. M. J. Nat. Prod. 2007, 70, 461.

6. (a) Burja, A. M.; Banaigs, B.; Abou-Mansour, E.; Burgess, J. G.; Wright, P. C. Tetrahedron 2001, 57, 9347; (b) Luesch, H.; Harrigan, G. G.; Goetz, G.; Horgen, F. D. Curr. Med. Chem. 2002, 9, 1791; (c) Gademann, K.; Portmann, C. Curr. Org. Chem. 2008, 12, 326 .

7. (a) Rickards, R. W.; Rothschild, J. M.; Willis, A. C.; de Chazal, N. M.; Kirk, J.; Kirk, K.; Saliba, K. J.; Smith, G. D. Tetrahedron 1999, 55, 13513; (b) Linington, R. G.; Gonzalez, J.; Urena, L.-D.; Romero, L. I.; Ortega-Barria, E.; Gerwick, W. H. J. Nat. Prod. 2007, 70, 397; (c) Linington, R. G.; Edwards, D. J.; Shuman, C. F.; McPhail, K. L.; Matainaho, T.; Gerwick, W. H. J. Nat. Prod. 2008, 71, 22.

8. (a) Becher, P. G.; Beuchat, J.; Gademann, K.; Jüttner, F. J. Nat. Prod. 2005, 68, 1793; (b) Becher, P. G.; Baumann, H. I.; Gademann, K.; Jüttner, F. J. Appl. Phycol. 2008, doi: 10.1007/s10811-008-9335-3.

9. Blom, J. F.; Brütsch, T.; Barbaras, D.; Bethuel, Y.; Locher, H. H.; Hubschwerlen, C.; Gademann, K. Org. Lett. 2006, 8, 737.

10. (a) Köhler, S.; Delwiche, C. F.; Denny, P. W.; Tilney, L. G.; Webster, P.; Wilson, R. J. M.; Palmer, J. D.; Roos, D. S. Science 1997, 275, 1485; (b) Ralph, S. A.; van Dooren, G. G.; Waller, R. F.; Crawford, M. J.; Fraunholz, M. J.; Foth, B. J.; Tonkin, C. J.; Roos, D. S.; McFadden, G. I. Nature Rev. Microbiol. 2004, 2, 203.

11. (a) Ralph, S. A.; D'Ombrain, M. C.; McFadden, G. I. Drug Resist. Updates 2001, 4, 145; (b) Sato, S.; Wilson, R. Curr. Top. Microbiol. Immunol. 2005, 295, 251.

12. (a) Noteberg, D.; Hamelink, E.; Hulten, J.; Wahlgren, M.; Vrang, L.; Samuelsson, B.; Hallberg, A. J. Med. Chem. 2003, 46, 734; (b) Vangapandu, S.; Jain, M.; Kaur, K.; Patil, P.; Patel, S. R.; Jain, R. Med. Res. Rev. 2007, 46, 734.

13. (a) Calas, M.; Ancelin, M. L.; Cordina, G.; Portefaix, P.; Piquet, G.; Vidal-Sailhan, V.; Vial, H. J. Med. Chem. 2000, 43, 505; (b) Ismail, M. A.; Brun, R.; Wenzler, T.; Tanious, F. A.; Wilson, W. D.; Boykin, D. W. J. Med. Chem. 2004, 47, 3658; (c) Ismail, M. A.; Brun, R.; Wenzler, T.; Tanious, F. A.; Wilson, W. D.; Boykin, D. W. Bioorg. Med. Chem. 2004, 12, 5405; (d) Hamze, A.; Rubi, E.; Arnal, P.; Boisbrun, M.; Carcel, C.; Salom-Roig, X.; Maynadier, M.; Wein, S.; Vial, H.; Calas, M. J. Med. Chem. 2005, 48, 3639; (e) Fujimoto, K.; Morisaki, D.; Yoshida, M.; Namba, T.; Hye-Sook, K.; Wataya, Y.; Kourai, H.; Kakuta, H.; Sasaki, K. Bioorg. Med. Chem. Lett. 2006, 16, 2758; (f) Calas, M.; Ouattara, M.; Piquet, G.; Ziora, Z.; Bordat, Y.; Ancelin, M. L.; Escale, R.; Vial, H. J. Med. Chem. 2007, 50, 6307; (g) Motoshima, K.;
Hiwasa, Y.; Yoshikawa, M.; Fujimoto, K.; Tai, A.; Kakuta, H.; Sasaki, K. ChemMedChem 2007, 2, 1527; (h) Mayence, A.; Pietka, A.; Collins, M. S.; Cushion, M. T.; Tekwani, B. L.; Huang, T. L.; Vanden Eynde, J.-J. Bioorg. Med. Chem. Lett. 2008, 18, 2658; (i) Torres-Gómez, H.; Hernández-Núñez, E.; LeónRivera, I.; Guerrero-Alvarez, J.; Cedillo-Rivera, R.; Moo-Puc, R.; Argotte-Ramos, R.; RodríguezGutiérrez, M.; Chan-Bacab, M. J.; Navarrete-Vázquez, G. Bioorg. Med. Chem. Lett. 2008, 18, doi: 10.1016/ j.bmcl.2008.05.009.

14. For dual mode of action drugs, see: (a) Gademann, K. Chimia 2006, 60, 841; (b) Bremner, J. B.; Ambrus, J. I.; Samosorn, S. Curr. Med. Chem. 2007, 14, 1459; (c) Meunier, B. Acc. Chem. Res. 2008, 41, 69.

15. (a) Wright, C. W.; Phillipson, J. D.; Awe, S. O.; Kirby, G. C.; Warhurst, D.; Quetin-Leclercq, J.; Angenot, L. Phytother. Res. 1996, 10, 361; (b) Kirsch, G.; Kong, G. M.; Wright, A. D.; Kaminsky, R. J. Nat. Prod. 2000, 63, 825; (c) Van Miert, S.; Hostyn, S.; Maes, B. U. W.; Cimanga, K.; Brun, R.; Kaiser, M.; Matyus, P.; Dommisse, R.; Lemiere, G.; Vlietinck, A.; Pieters, L. J. Nat. Prod. 2005, 68, 674. 